\title{
TITLE:
}

\section{Unit Groups of Chimpanzees and Their Nomadism in the Savanna Woodland(Abstract_要旨)}

\author{
AUTHOR(S): \\ Izawa, Kosei
}

\section{CITATION:}

Izawa, Kosei. Unit Groups of Chimpanzees and Their Nomadism in the Savanna Woodland. 京都大学, 1970, 理学博士

ISSUE DATE:

1970-11-24

URL:

http://hdl.handle.net/2433/213518

RIGHT: 


\section{[3]}

氏名伊梁紘生

学位の種類 学位記番号 学位授与の日付 学位授与の要件 研究科・尃攻 学位論文題目

理学 博士

理 博 第 200 号

昭 和 45 年 11 月 24 日

学 位規則第 5 条第 1 項該 当

理学研究科動物学専攻

\section{Unit Groups of Chimpanzees and Their Nomadism in the Savanna Woodland}

（サバンナ・ウッドランドに抒けるチンパンジーの単位集団とそれ らの遊動について)

論文調査委員教授池田次郎教授森主一教授近藤四郎

\section{論文内容 の要旨}

申請論文は，申請者が1963年から1967年にかけて，通算600日，2回にわたっておこなった，東アフリ カ，タンガニイカ湖束岸カサカティ盆地における野性チンパンジーの生態学的研究の結果をまとめたもの である。この地方は，サバンナ・ウッドランド帯で，申請者は参考論文の一つにおいて，ての環境につい ての詳細な分析をおてなっており，主論文においては，ての基盤の上に立って，チンパンジーの集団上そ の遊動を主題とした分析を展開している。

申請者は，カサカティ盆地のほぼ中央に基地を設営し，ててを中心として視聴覚によってチンパンジー の遊動を把握しうる約 $45 \mathrm{~km}^{2}$ を，イティティエ・カサカティ地域（I・K地域）として設定し，いわばこれ を一つの大きなコードラートとして，乙の地域に出入りし自由な遊動を枋てなうチンパンジーの集団の追 跡をおこなった。

その結果，I・K地域を訪れるチンパンジーは，約110頭からなるととが推定され，それはZおよびL々

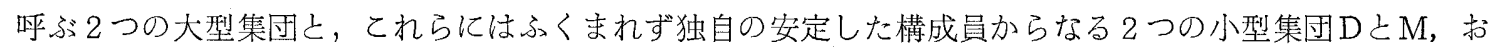
よび相当の長期にわたって単独の生活を営む単独行動者からなっているととが明らかにされた。

これらのうち，Z約50頭で，その30頭までが個体識別によって確認され，Lは約40頭と推定された。 小型集団Dは 3 頭からなり，少なくとも約150日間の持続が，またMは 8 頭からなり，少なくとも25日間 の持続が確認された。単独行動者は45例が記録されたが，成獣のオスがそのうちの64\%を占めている。単 独行動の持続を立証する資料は少ないが，同一のオスのもの之推定される地面に印されたナックル・プリ ントの約100日間の追跡の例がある。

大型集団 $Z$ 之Lは，それぞれ 約 $120 \mathrm{~km}^{2}$ の安定した遊動域をもち，その $21 \% ，$ 約 $26 \mathrm{~km}^{2}$ は， I $・ \mathrm{~K}$ 地域の 中で重複している。とれに対して，小型集団注大型集団の遊動域の中できままな遊動を示し，独自の遊動 域をもたない。申請者は，小型集団の遊動域は，大型集団の遊動域よりもより広範に及ぶにちがいないよ 推定している。 
社会構成は, 大型集団 $Z$ について，ほほ完全に明らかにされ，同時にその内部構造の検討がおこなわれ ている。しかし，乙れらの構成員は，つね激しい離合集散圭繰り返し，団子の結びつきを除いては，単 位集団の部分檏造と考えられるような形態は，何一つ見出しえなかったという。

申請者は, 単位集団の全体の遊動時における状態を, 密集状態, 分散状態, 分割状態という3つの類型 に分け，季節的な食物の推移之集団の遊動のパターンを迫いながら，大型集団の単位集団としての恒常性 と安定性を立証するととに成功している。同時に，離合集散は，必らずしも食物生産に刘応した適応的な 傾向ではなく，チンパンジーの社会があつ本質的な特性であることが指摘された。なお，集団の季節的な 遊動は，I・K地域に入るために用いられる6つのパスのうちのよ゙れを用いるかによって類型化され㸴節的 な遊動の特徵が示された。

集団の遊動の追跡の中から，大型集団ZLLの集団間関係が捉えられたのは，乙の研究の優れた成果の 一つである。上述のように，大型集団は遊動域の一部を互いに重複させているが，お互いの主要遊動域の 中にあえて入ることはなく，接近した場合にも互いに他を避けあっているととが見出された。

申請者は，以上の諸観察之分析の上に立って，大型集団が，サバンナ・ウッドランド帯に棲息するチン パンジーの基本的な社会形態であるとし，小型集団は，単独行動者等の参加を可能にしながらゆくゆくは 大型集団に䏍ってゅく，チンパンジーの社会単位の崩芽的な存在であろうという位置づけを抗てなってい 万。

\section{論文審查の結果の要旨}

近年に至って，野生チンパンジーの野外調査は日本，英国，オランダなどの研究者によって進められ， 行動, 社会関係, 社会構造, 環境への適応, 分布等の課題が取り上げられ，他の霊長類（ヒトを除く）上 の著るしい相違点が注目されるようになった。てれらの研究の中にあって，申請論文に扔いては，飭づけ によらない純野生状態のチンパンジーに対するオーソドックスな生態学的なアプローチがとられて抢り, このアプローチが扔のずから研究の梁度にある限界を画しはしたが，よく単一の集団を越えた野生チンパ ンジーの社会の断面を捉え得たものとして，高く評価するとしがでさる。

この研究フィールドは，広大なサバンナ・ウツドランド帯であるが，申請者は約 $45 \mathrm{~km}^{2} の$ 広さをもつ $\mathrm{I}$ ・K 地域を設定し, 申請者によって知悉されたこの地域に出入りするチンパンジーの集団を追って，イン テンシヴな調查を展開している。てれは，広大な自然対象しした独自な方法であると同時に，てれがこ の困難な調查を成功汇導いた基礎をなしたといってよいであろう。

まず，申請者は，観察を通じて，この地域にチンパンジーが入りかつ出てゆく6つのパスを見出し，利 用されたパスの組み合せによって集団の遊動の類型化をはかり，各季節の遊動の特性をあらわしている。 このように, この研究においては単位集団の発見, その持続性と安定性, 集団の遊動の状態, 集団の社会 構成，その内部構造，集団間関係に至るまで，乙れらのすべてが，遊動の追跡を通じて捉えられている。

野性チンパンジーの社会的単位は，もっ上あ困難な課題であり，乙扎は西田（1968）による慨づけに成 功したチンパンジーの集団の分析によって確証に導かれたのであるが，申請者は時期的にはとれとほぼ平 行して，しかも純野性のものを対象としながら，50碩内外からなる大型の集団がチンパンジーの基本的な 
社会形態であるという，西田と同様の結論に達している。

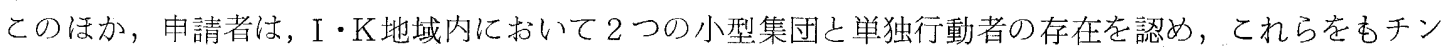
ンパンジー社会の基本的要素を構成するものと考え，とくに前者では，いずれは大型集団に成長する崩芽 的な存在であろうという推定を下している。とれは重要な提言であるだけに，その根拠となる資料の不充 分さが喈しまれるのであるが，とれを実証に導くためには，はるかに長期の調査が必要であり，おそらく この種の調查が㧍となわれるとよはもはやないであるう。遊動の具体的な分析を通じて，集団間の相互関 係が求められているが，ての部分は先駆的な成果であり，ての論文の評洒を高めている。参考論文中の第一 は，主論文でとり扱っているチンパンジーの生息域の環境を詳細に分析したものであり，第 2 , 第 3 は寒 冷地における野生ニホンザルの生態学的研究であって, 主論文と之もに申請者の広い学識を示している。 よって，本論文は，理学博士の学位論文として価值あるものと認める。 